\title{
CHINA'S HUNT FOR FUEL THROUGH BRI IN THE MIDDLE EAST
}

\section{Fakhar Hussain $^{*}$, Mian Saeed Ahmad ${ }^{2}$, Shumaila Rafiq ${ }^{3}$, Umm-E-Rubab ${ }^{4}$, Sarfraz Hussain ${ }^{5}$}

${ }^{1 *}$ Lecturer in Civics at Government Imamia Associate College Sahiwal, Pakistan; ${ }^{2}$ Assistant Professor, Department of

Pakistan Studies, The Islamia University of Bahawalpur, Pakistan; ${ }^{3}$ Lecturer, Department of Political Science and International Relations, University of Gujrat, Pakistan; ${ }^{4}$ Government College University Faisalabad, Pakistan; ${ }^{5}$ Assistant Professor (Commerce), Government Graduate College Liaqat Road Sahiwal, Pakistan.

Email: ${ }^{1 *}$ diplomat786@gmail.com, ${ }^{2}$ mian.ahmad@iub.edu.pk, ${ }^{3}$ shumaila.rafique@uog.edu.pk, ${ }^{4}$ u.rubab20@ yahoo.com, ${ }^{5}$ mianfraz1@gmail.com

\section{Article History: Received on $14^{\text {th }}$ June 2021, Revised on $30^{\text {th }}$ June 2021, Published on $14^{\text {th }}$ July 2021}

\begin{abstract}
Purpose of the study: The purpose of the study is to examine China's hunt for the acquisition of energy supplies through the Belt \& Road Initiative (BRI) in the Middle East due to the unprecedented economic expansion on accounts of which it needs reliable resources of natural gas and oil to cope with the requisite needs of energy.

Methodology: The data for this study is collected from various secondary sources like Research Journals, Academic Research Papers, and Electronic Sources. Data were interpreted using the deductive method of investigation through an analytical and descriptive approach.

Principal Findings: The main findings indicate that China has long followed its "win-win" strategy, which means that all trading partners of the region profit fairly, and for that reason, Beijing is aiming to boost its commercial presence in the region of the Middle East for mutual gains and that economic interdependence, according to Beijing encourages collaboration between the states on accounts of which it is considered that energy deals of China are centered on mutual economic interests.
\end{abstract}

Applications of this study: Findings of the study will be helpful for scholars and academics of International Relations, Security Studies, Policymakers of China and the Middle East countries, diplomats of China, USA, Russia, Saudi Arabia, and Iran as well as it also contributes for understanding energy and economic ambitions of China in the region of Middle East, which to be accomplished through BRI.

Novelty/Originality of this study: The originality/novelty of the study lies in the attempt to explore that BRI is considered as the $21^{\text {st }}$ century's Marshall Plan by China and that it will associate China's hunt for global energy resources by diversification of the economic markets of the Middle East.

Keywords: Economic Expansion, Oil Industry, The Dragon, Economic Collaboration, Energy Consumer.

\section{INTRODUCTION}

China has never remained to be a newcomer to the Middle East on accounts of its embryonic relationship with the region (Zha \& Michal, 2015). The Middle East and China have been in communication for at least two centuries (Gordon \& Noureddin, 2019). Throughout the $9^{\text {th }}$ century, the merchants of Arabia often traveled across the prosperous oceanic pathways interweaving the Persian Gulf and southern areas of China via the Indian Ocean. The trading activities involving the business of luxurious goods, silk, and jade continued for centuries, eventually becoming a part of the ancient Silk Road (James, 2011). The Silk Road was used for trade between China and the Middle East throughout the Muslim Empires of the Umayyad and Abbasid periods (Gordon \& Noureddin, 2019). The socio-cultural reciprocal links between the Chinese and the Arabs have constantly remained solid based on their long-standing cultural connections to the extent that they continue to strengthen these bonds through exhibitions and student exchange programs from the past to the present (Sharma, 2019). The Merchants of Arabia traveled along the 4,000 mile Silk Road for business and trade of ivory, rugs, silk, spices, camels, and horses (Gordon \& Noureddin, 2019).

During the early twentieth century's era of expansionism, technological developments aided western nations' desire to utilize oil as a newly valued fuel for aircraft, automobiles, and other applications (Besada \& Salam, 2017). The countries of the Middle Eastern region have been in ownership of the world's main reservoirs of crude oil and gas (Massoud, 2009) encompassing the crude oil reserves of about 800 billion barrels, the region of Middle East turns out to be a prominent actor of the global energy market (Besada \& Salam, 2017). The most extensive oil resources of the Middle East accounts for more than 60\% of the economy of the world's (Sun, 2011) estimated possession of supplies about $47 \%$ of China's imports of oil, which has been projected by 2035 with a growth of 72\% (Manochehr \& James, 2013).

Asia will be going to emerge as the centre of intra-regional economies under the dynamics of the evolving worldwide commercial and trading order, whereas countries of the Middle Eastern region have become a significant source of fuel (Rasel et al., 2020). The area of the Persian Gulf remains the oil industry's "economic centre of gravity," encompassing the largest oilfields of the world, the lowest production rates, and about two-thirds of the proven global reserves of energy (Manochehr \& James, 2013). The Middle East has remained to be well-known in the past for its plentiful resources of energy, which were previously exploited by the major powers (Zhexin, 2018) because it has been a central area for power games and competition based on its critical geopolitical position and abundant oil and gas reserves 
(Engin, 2015). Since ancient times to the present, the Middle East has always been a strategic hotspot for contending global powers in the region due to its geostrategic significance. Following WWI and the downfall of the Ottoman Empire, France, and Great Britain signed an infamous treaty of "Sykes-Picot" and seized control of the region (Besada \& Salam, 2017).

The relationship between the Middle Eastern states and China has rapidly grown, from the inception of the People's Republic of China (PRC) to the end of the Cold War era (Massoud, 2009). These relations were established under the Cold War's ideological and strategic perspectives (Ehteshami, 2018). The Communist Party of China and Mao Zedong introduced reforms in the early 1950s regarding centrally planned command of the economy, as well as Mao also ordered for the formation of being the $1^{\text {st }}$ Division of the People's Liberation Army (PLA) unit of oil in 1952 for the development of China's unexploited reserves of oil (Michal, 2016). China's first diplomatic victory in the Arab world occurred in 1956 when it established a diplomatic relationship with Egypt under the reign of Mao (Massoud, 2009). The era of Mao Zedong has been considered significant during which the foundations of China's growing energy consumption were laid, and the oil industry of China was shaped (Sharma, 2019). With the continuation of China and the Middle East deepening relations concerning energy supplies, efforts for extension and strengthening diplomatic links with the Middle East countries were also made in the past (Rasel et al., 2020). Mao was passionate about developing the country's oil resources to become self-sufficient (Michal, 2016). Later on, Hu Jintao suggested the idea of a "Harmonious Middle East," whereby the pursuit of Beijing's prolonged associations is based on seeking mutual interests and reverence for independence and sovereignty (Manochehr \& James, 2013). The region of the Middle East was deliberated to be a vantage point for China regarding the establishment of the balance of power between the US and the USSR (Shichor, 2018). The strategic relationship between countries of the Middle East and China entered a novel phase due to the emergent role of China in world affairs since the conclusion of the cold war in 1989 (Sharma, 2019).

China adopted the "Zou-Chu-Qu" policy of going out in 2001 (James, 2011). The great dragon (China) appears to be planning for nesting for a long term stay in the regional domains of the Middle East by strengthening its roots in the economic affairs of the region and by validating treaties with major oil-producing countries regarding supplies of energy at the dawn of the second decade of the $21^{\text {st }}$ century (Zhexin, 2018), and that China may no longer remain aloof to the oil-rich countries of the Middle Eastern region (James, 2017). China's energy policy is intrinsically interlinked to the Middle East states (Garlick, 2020). The security of the smooth supplies of oil is a crucial concern regarding Sino-Middle East relations to the extent that China has already made efforts to be hedged against the probable impacts of any disruption of energy supplies (John, 2014). Beijing concentrates on the acquisition of energy supplies due to the unprecedented economic expansion of the country, on accounts of which it needs reliable resources of natural gas and oil to cope with the critical needs of energy (Rasel et al., 2020). The region of the Middle East has turned out to be a viable source of oil for China for securing needs of energy supplies. It has been heavily dependent on Middle Eastern oil and wishes to establish long-term trading ties with the region (Zhao, 2007).

China introduced an "equity ownership" policy for gaining control of the management of oil resources and utilized the strategy as a shield against the fluctuations of oil prices in the market (Zhexin, 2018). The bilateral collaboration between the Middle East and China in the energy sector is based because China necessitates gas and oil from the Middle Eastern countries, whereas states of the Middle East desire access to the economic market of China (Qian, 2014). Under the dynamics of China's reliant on the increasing demands of gas and oil from abroad, the enhancement of the objectives of China's national interests will be difficult to pursue because it will be prone to the vagaries of the international markets of energy supplies and insecurity in the oil-producing region of the Middle East (Manochehr \& James, 2013). The security of energy supplies and resources is indispensable for the economy's growth and is also significant for the establishment of peace and tranquillity in a country. One of the most critical facets of securing energy is ensuring a steady oil supply (Besada \& Salam, 2017).

The strategic partnership concerning energy between the Arab states and China in recent years has to be establishing with fluxes based on political turmoil in the region of the Middle East (Qian, 2014). The incident of 9/11 and the start of a global war against terrorism in the broader context gave a sense of vulnerability to China concerning imports of its oil supplies through the Middle East (Johnston, 2018) on accounts of which the policymakers of China had to consider for novel sources of energy for ensuring the security China's energy needs (Ehteshami, 2018). The conflicts and political disorder in the region of the Middle East intimidate for disruption of energy supplying conduits of China, implying that China may work to establish peace and tranquillity in the area for maintaining smooth supplies of energy (Sarieddine, 2021).

The BRI plan by Xi Jinping was unveiled as an umbrella venture in 2013 to seek access towards novel economic markets and to help China (Sharma, 2019) for achieving long-term economic development by securing networks of global supplies based on which to maintain socio-economic stability at home (Shichor, 2018). The Middle East has been considered significant in geographic terms because it is located at the crossroads of imperative trading routes and strategic sea-lanes of communication interlinking Asia to Africa and Europe (Johnston, 2018). It is also crucial for the potential growth of BRI, which aims for the placement of China at the centre of global networks of trade (Camille et al., 2019). The BRI has both land-based and maritime components. The Marine Silk Road Initiative (MSRI) is a nautical portion of the Silk Road Initiative that connects China to the continents of Europe and Africa via the Middle East 
(Sarieddine, 2021), whereas the Silk Road Economic Belt (SREB), its land-based equivalent seeks to interlink China and Europe, mainly through Central Asia (Hussain \& Hussain, 2017), but also to a lesser extent using the Middle East (Lisa, 2019).

\section{The Objective of the study}

To explore China's energy interests in the region of the Middle East after becoming the largest consumer of energy in the world. As a result of its fast economic expansion, China has emerged as the biggest customer of fuel. China has become the world's 2nd biggest oil user next to the US, accounting for $12 \%$ of global energy consumption and importing about one-third of its total energy supplies from overseas.

\section{REVIEW OF LITERATURE}

Besada and Salam (2017) analyzed that Asia is going to emerge as the centre of intra-regional economies under the dynamics of the evolving worldwide commercial and trading order, whereas the countries of the Middle Eastern region have become a major source of fuel. Since the Middle Eastern states lack human resources, China has the potential to export labour services to the Arabs. China has become a major trade partner in the region based on its complementarity to the Middle Eastern countries (Besada \& Salam, 2017).

Zha and Michal (2015) examined that China's overall oil intake is forecast to increase to the point that it will be the leading contributor to the global demand for growth. China's consumption of energy is projected to exceed the demands of the US and may reach $18 \mathrm{Mb}$ on a daily basis by 2035 . China is now seeking stronger economic relations with countries of the Middle East to increase the trade of energy supplies, which is intended to reduce China's trade imbalance while opening up novel investment opportunities, particularly as Beijing pursues through its "One Belt, One Road" initiative (Zha \& Michal, 2015).

Qian (2014), in his article, discussed that the bilateral collaboration between the Middle East and China in the energy sector is based because China necessitates gas and oil from the Middle Eastern countries, whereas states of the Middle East desire access to the economic market of China. The crude oil imports from countries of the Middle-East region provide for more than $56 \%$ of the overseas supplies of China's crude oil needs. The collaboration between the Middle East and China reveals the inclusive trend that China and the Middle East may attain mutually advantageous outcomes based on working together (Qian, 2014).

Manochehr and James (2013) investigated that the great dragon (China) appears to be planning for nesting for a long term stay in the regional domains of the Middle East using strengthening its roots in the economic affairs of the region and by validating treaties with major oil-producing countries regarding supplies of energy at the dawn of the second decade of the 21 st century. China is an emergent power capable of counterbalancing the hegemonic plans of the US and its unipolar existence, with a long history of trading through the ancient Silk Road with the Middle East, while having no history of imperial supremacy in the regional framework (Manochehr \& James, 2013).

Massoud (2009) highlighted that China's policy regarding the supply of oil from the Middle East has become considerably significant due to its economic boom. China's inactivity in the area has ended to the extent that Beijing has been attempting to secure the smooth supply of energy to ensure the ongoing expansion of a rapidly emergent economy. China will be capable of playing the increasingly active role of the regional framework through BRI to ensure its energy security (Massoud, 2009).

Zhao (2007) pointed out that the incident of $9 / 11$ and the start of a global war against terrorism in the broader context gave a sense of vulnerability to China concerning imports of its oil supplies through the Middle East on accounts of which the policymakers of China had to consider for novel sources of energy for ensuring the security China's energy needs. The region of the Middle East has turned out to be a viable source of oil for China for securing needs of energy supplies. It has been heavily dependent on Middle Eastern oil and wishes to establish long-term trading ties with the region (Zhao, 2007).

\section{China's Hunt for Fuel through BRI in the Middle East}

China's continued growth and development makeover depend on maintaining adequate supplies of oil (Besada \& Salam, 2017). China merely produces about $44 \%$ of its total oil requirements (Naser, 2012). China's concerns regarding the security of energy and supplies of oil have grown after it lost oil self-sufficiency (Besada \& Salam, 2017). Some of Beijing's key aims, such as the prompt growth of the commercial endeavors, supplies of energy, and economic assets from outside resources, are becoming more pressing and tangible, particularly related to the country's ongoing internal modernization (Mordechai, 2019). Beijing's engagement policy remains the need to secure essential resources of energy needed to sustain a rapid commercial development in the face of increasingly volatile global energy markets (Chris \& Brandon, 2008).

With 1.3 billion inhabitants and the $2^{\text {nd }}$ biggest commercial market in the world, China has an ever-increasing need for oil. Because of its rapid economic growth, China had become an oil importer by 1993 (Besada \& Salam, 2017). Beijing's yearly GDP rose by the ratio of an average of 9\% between 1990 and 2000 (James, 2011). China's oil import 
growth declined by $30 \%$ in 2005 , owing in part to the increasing market price of oil, and the overall dependence of China on oil imports was substantially reduced (Massoud, 2009). China imported about 53 billion cubic meters of natural gas in 2013, increasing the country's dependency on imported gas to 31.6 percent, surpassing the value of 30 percent for the first time (Qian, 2014). Because of the decline in global oil prices in 2015 and China's rising position as a great power and major energy player, Beijing is trying to hold politics and economy apart in the Gulf region while implementing an effective energy security strategy (Camille et al., 2019).

China, the world's 2nd largest economy, is anxious for energy supplies to keep up with its rapid economic growth (Besada \& Salam, 2017). China has used an equity investment strategy to gain greater control over oil flows, shielding itself from price volatility and lowering the chance of supply interruption (Sarieddine, 2021). According to the prediction of the "International Energy Agency," over the next 25 years, the commercial industry of China will be accounting for more than twenty percent growth of the global energy demand (Massoud, 2009). As a result of its fast economic expansion, China has emerged as the biggest customer of fuel (Zha \& Michal, 2015). China's oil requirement was forecast to rise from $7.7 \mathrm{Mb}$ "million barrels" daily in 2008 towards about $16.5 \mathrm{Mb}$ per day up to 2030 and to be accounting for $42 \%$ of the global need for oil (Manochehr \& James, 2013). The consumption of energy in China per GDP in average US\$ is currently more than three times the United States; about five times of Japan and also eight times of the United Kingdom (Guang, 2008).

China and the Middle Eastern countries have shared interests in the energy sector (Besada \& Salam, 2017). China's regional influence has grown considerably in recent years (Chris \& Brandon, 2008), for which it has become a more significant player in the Middle East (Michal, 2016). Beijing's interest originated mostly from the country's desire for oil in the Middle East when it became understood that the production of energy resources was not enough to meet China's growing demand for energy supplies (Besada \& Salam, 2017). The crude oil imports from countries of the Middle-East region provide for more than 56\% of the overseas supplies of China's crude oil needs (Qian, 2014).

China also developed an equity ownership scheme to ensure its continuous oil supplies. Chinese companies have pursued equity shares in overseas oil ventures with the expectation of having better leverage over oil flows and probably to lessen the disruption of energy supplies (Besada \& Salam, 2017). The three oil corporations of China employed to come across its interests regarding energy security are namely the China National Offshore Oil Corporation (CNOOC), the China Petrochemicals Corporation (Sinopec), and the China National Petroleum Corporation (CNPC) (Michal, 2016). China Petroleum Engineering and Construction Corporation (CPECC) in 1983 in Iraq and Kuwait, while the Great Wall Drilling Company (GWDC) of China acquired drilling opportunities in Egypt, Qatar, Oman, and other Middle Eastern countries (Besada \& Salam, 2017). Even though the firms of China are playing a crucial role in ventures of oil exploration in the Middle Eastern countries such as Oman, Kuwait, Syria, Qatar, Iraq, Yemen, and the UAE as well Iran and Saudi Arabia (Alterman \& Graver, 2008), Beijing's first upstream investment and procurement in the Middle East was in Iraq. China is active in the business of oil as well as drilling and engineering in the countries of the Gulf Cooperation Council (GCC) like Oman, Kuwait, Bahrain, the United Arab Emirates (UAE), and Saudi Arabia (Besada \& Salam, 2017).

The "One Belt, One Road" plan by Xi Jinping shows that Chinese enterprises would be welcomed in the economic markets of the Middle East, especially in the upstream oil industry (Blanchard, 2021), based on which Qatar, the world's largest producer of liquefied natural gas (LNG), has recently established its strategic relationship with China for its participation into the "Silk Road Economic Belt." Since the 1970s, Kuwait has commercial associations with Beijing, as well as China, has also invested about $\$ 600$ million in Oman in the fields of petrochemicals, oil, and development of infrastructure for transportation of oil (Besada \& Salam, 2017).

The production of oil in China increased so rapidly that it began to export oil in 1985 and reached the peak level of about 6.21 million tons of oil exports (Guang, 2008). China's basic demand for energy consumption was raised from nearly 24 million-ton coal equivalent (MTCE) in 1949, which reached 50 MTCE in 1952, and more than 500 MTCE in 1976 (Michal, 2016). The discovery of oil in the Daqing oilfield in the Northeastern area of China in 1959 ensured that the volume of oil discovered will be enough for China to maintain self-sufficiency and that supplies of energy from abroad will not remain an issue for the growing economy of China (Besada \& Salam, 2017). During (1949-76) the era of Mao Zedong, China's commercial energy industry grew rapidly because the country adopted an industrialization model for the development of the economy. Similarly, the need for energy supplies also began to rise (Zhexin, 2018). Since the 1990s, the topmost priority of China is associated with the smooth supply of oil from abroad because the shortfalls of energy resources may pose threats for the growing economy of China (Himaz, 2019). For the time being, as an Asian giant, China has appeared to be the world's leading energy user and only $2^{\text {nd }}$ to the United States in terms of the consumption of oil (Manochehr \& James, 2013).

Since it became a net buyer of oil in 1993, the engagement of China in the Middle East is associated with the acquisition of energy due to the urgent needs of natural gas and oil resources to sustain the rapid growth of its economy (Manochehr \& James, 2013) and to employ people as well to seek new economic markets for export of Chinese goods, but also to find novel resources of energy for the running of factories and rise of the economy (James, 2011). China has emerged as the world's $2^{\text {nd }}$ biggest economy, the top trader of industrial products, and the largest energy user (Manochehr \& James, 
2013). China's demand for oil surged abruptly since it became a member of the World Trade Organization (WTO) in 2001. China has surpassed the US as the world's leading driver of rising oil consumption globally (Zha \& Michal, 2015).

China has now become the largest producer and importer of crude oil, giving it significant weight in the global oil business (Michal, 2016). China has been procuring oil from the world's 30 countries (Guang, 2008). It has purposefully deepened its political, commercial, and social affiliation with regional countries since 1993s after becoming a net trader of oil (Manochehr \& James, 2013). Since the mid-1990s, China has been revising its strategy regarding security and growth of energy, following a plan to develop overseas supplies of energy. The role of the Middle East is crucial (Guang, 2008). China used to acquire the majority of its foreign supplies of energy from the regions of the Asia Pacific and the Middle East, but since 2004, the Indonesian shift from oil-exporter to the importer of oil has created a gap in the regular energy suppliers of China (Zhao, 2007).

Since becoming a net customer of petroleum (Guang, 2008), China in 1993 imported a net volume of about 9.91 million tons of crude (MTC) oil (Alterman \& Graver, 2008). China's oil imports dropped marginally from 1994 to 1995 to the ratio of about 3.30 and 8.75 MTC respectively, whereas they increased at a fast pace after 1995 (Guang, 2008). China's rapid growth of oil consumption has prompted the country to transition from an exporter of oil to a state of the net importer of oil. The gross energy use of China turned out to be twice with the increase from about 57,144 tons of coal equivalent (TCE) to around 128,000 TCE between 1978 and 2000 (Besada \& Salam, 2017). China has imported 70 million tons of petroleum by the year 2000, accounting for more than 220 million tons, equivalent to $1 / 3$ of China's overall consumption of oil (Manochehr \& James, 2013). The petroleum imports of China amounted to 90 million tons in 2003 (Alterman \& Graver, 2008). China made a historical record of importing crude oil to the quantity of 163 million tons, providing 40 percent of national consumption of oil in 2007 (Guang, 2008).

The oil consumption of China reached to peak in 2012 at $9.5 \mathrm{Mb}$ for a single day. The USA was surpassed by China in terms of being the biggest user of energy in 2013, with the total value of exports and imports reaching US\$ 3.87 trillion (Besada \& Salam, 2017). Beijing's apparent intake of oil in 2013 was 498 million tons, nearly 1.7 percent increase over the previous year, while the quantity of consumed crude oil was 487 million tons, about a 2.8 percent increase over 2012, while in comparison to 2012, growth rates fell by 2.8 percent and 1.7 percent respectively (Qian, 2014). Beijing's influence in global energy markets has expanded previously between 2003 and 2013, accounting for an increase of $60 \%$ in the global demand for energy (Zha \& Michal, 2015). China's reliance on overseas oil was 58.1 percent in 2013, almost similar to the levels of 2012 (Qian, 2014). In 2013, the natural gas demand of China had to be about 167.6 BCM, nearly with a rise of approximately 13.9 percent over the preceding year. The demand for gas accounted for 5.9 percent of overall primary energy consumption in China in 2013, which was 5.4 percent in 2012 (Zha \& Michal, 2015). According to the International Petroleum Network, China imported $564 \mathrm{Mb}$ of the fuel per day, nearly $281.962208 \mathrm{MTC}$ oil per year in 2013, and an increase of 4.03 percent over 2012 (Manochehr \& James, 2013). China in 2014 used 10.4 Mb oil per day (Zha \& Michal, 2015). Beijing's demand for oil in 2014 rose to about 4 percent by reaching 518 MTC (Qian, 2014).

\section{RESEARCH METHODOLOGY}

This study is explanatory and qualitative. The significance of BRI as a driver of China's soft power leverage was assessed by data analysis contributing to explore the collaboration amid countries of the Middle East region and China reveal the inclusive trend that both China and the Middle East may attain mutually advantageous outcomes based on working together in the regional framework. During this exploratory study, the participation and role of major regional and global actors of the region such as Saudi Arabia, Iran, the USA, China, and Russia and the reactions of all concerned parties had been examined thoroughly. During this investigation, the available material from secondary sources was retrieved and reviewed. The relevant data from research articles, websites, journals, and newspaper editorials had been collected and analyzed for a comprehensive analysis.

\section{RESULTS AND DISCUSSIONS}

Beijing's oil imports rose from about $2 \mathrm{Mb}$ per day in 2002 to $6.2 \mathrm{Mb}$ daily in 2014, with peaks of $7.4 \mathrm{mb} / \mathrm{d}$ in the mid of 2015 (Zha \& Michal, 2015). The statistical review report of the World Energy by British Petroleum in 2014 indicated that China emerged as the largest consumer and producer of overall world's energy in 2013 (Naser, 2012). Over the next 25 years, global energy demand will increase by one-third, with China accumulating for a nearby $30 \%$ of the entire growth. The global oil demand is predicted for a rise in 2009 from $74 \mathrm{Mb}$ per day to $99 \mathrm{Mb}$ per day in the year 2035, and that China has been projected to use more than an extra $25 \mathrm{Mb}$ of oil daily, which too is purchased by the overseas markets (Manochehr \& James, 2013). China's demand for oil has been growing, with an average quantity of 450,000 barrels of oil per day on an annual basis (Zha \& Michal, 2015). It has been estimated that by 2035, China will have firmly established itself as the world's largest energy consumer while consuming up to $70 \%$ more energy than the US (Manochehr \& James, 2013). China's overall oil intake is forecast to increase to the point that it will be the leading contributor to the global demand for growth. China's consumption of energy is projected to exceed the demands of the US and may reach $18 \mathrm{Mb}$ on a daily basis by 2035 (Zha \& Michal, 2015).

Xi Jinping advocated for an "energy revolution" to decrease the speed of expansion in energy utilization as being a part of China's "new normal" strategy of development which tolerating the slower aggregate economic growth (Blanchard, 
2021). China's foreign investments have drastically enhanced in the region of the Middle East during the $21^{\text {st }}$ century, particularly in the fields of the development of infrastructures, project management of natural resources, and energy production (Garlick, 2020). For the time being, no other nation will match the Middle East's primary role in the overall foreign strategy of China for the development of energy in the future (Guang, 2008).

China continuously desires to seek access to the untapped consumer markets as well as lucrative investment opportunities for its imports (Chris \& Brandon, 2008). China is an emergent power capable of counterbalancing the hegemonic plans of the US and its unipolar existence, with a long history of trading through the ancient Silk Road with the Middle East, while having no history of imperial supremacy in the regional framework (Manochehr \& James, 2013). The traditional security and foreign policy strategy of China in the Middle East is based on the notion of nonintervention in the domestic affairs of other states (Blanchard, 2021), which would surely have an increasing effect on the Middle Eastern diplomacy of Beijing, leading China for taking a more active role in the economic and political arenas of the region (Guang, 2008).

The dragon (China) has probably to nest for decades in the Middle East through BRI for the pursuit of its strategic objectives in the regional framework (Blanchard, 2021). China is using soft power leverage in the Middle Eastern region (Zhiqun, 2009). China has long followed its "win-win" strategy, which means that all trading partners of the region profit fairly (Besada \& Salam, 2017), and for that reason, Beijing is aiming to boost its economic presence in the Middle East for mutual gains (Himaz, 2019). Economic interdependence, according to Beijing, encourages collaboration between the states (Manochehr \& James, 2013), on accounts of which it is considered that energy deals of China are centered on mutual economic interests (Massoud, 2009).

The rising dragon (China) is extending its commercial activities from hydrocarbon markets of the Middle East to across the world through the BRI venture (Ehteshami, 2018). Under the dynamics of regional politics, the countries of the Middle East want China to play a bigger role in the regional domains (Jon B, 2013). Mutually advantageous joint ventures in mining, manufacturing, petrochemicals, and the development of infrastructure projects underpin the SinoMiddle East strategic partnership, which is based on reciprocated economic and political interests (Garlick, 2020). The Chinese economy's fast growth is currently slowed by increasing insufficiency of domestic oil and gas supplies. The reliance of China on foreign energy supplies is mounting due to its rapidly growing requirements for energy. China needs Middle Eastern gas and oil, while the countries of the Middle East desire access to the economic market of China, which provides grounds for the establishment of mutual collaboration (Qian, 2014). Similarly, China also seeks access to energy resources of the Middle East to fuel its economic expansion (Himaz, 2019).

China will be capable of playing the increasingly active role of the regional framework through BRI to ensure its energy security (Blanchard, 2021). Dragon's foothold in the region of the Middle East has gradually developed to the regional energy interests because China's dependence on the Middle Eastern energy resources is growing (Ehteshami, 2018). China needs an abundance of Middle Eastern gas and oil to expand its economy and ensure the Beijing regime's survival (Engin, 2015). The collaboration between the Middle East and China reveals the inclusive trend that China and the Middle East may attain mutually advantageous outcomes based on working together (Qian, 2014). Through its "One Belt, One Road" initiative, China will associate the hunt for global energy resources with the diversification of the economic markets of the Middle East (Himaz, 2019). Since the Middle Eastern states lack human resources, China has the potential to export labour services to the Arabs. China has become a major trade partner in the region based on its complementarity to the Middle Eastern countries (Sarieddine, 2021). Beijing authorized its employees, groups, and organizations to offer labour in construction projects and give advisory services in the Middle Eastern markets (Ehteshami, 2018).

China's policy regarding the supply of oil from the Middle East has become considerably significant due to its economic boom. The Middle Eastern states have become the main customers of China's machinery, industrial goods, vehicles, equipment, foodstuff, and labour services (Alterman \& Graver, 2008). China's inactivity in the area has ended to the extent that Beijing has been attempting to secure the smooth supply of energy to ensure the ongoing expansion of a rapidly emergent economy (Himaz, 2019). The BRI of China aims to invest and develop infrastructure in the Middle East and other parts of the world from the commercial point of view (Johnston, 2018).

\section{CONCLUSION}

It is imperative to conclude that the region of the Middle East remains the oil industry's "economic center of gravity," encompassing the largest oilfields of the world, the lowest production rates, and about two-thirds of the proven global reserves of energy. It is also crucial for the potential growth of BRI, which aims for the placement of China at the center of global networks of trade. The BRI plan by Xi Jinping was unveiled as an umbrella venture in 2013 to seek access towards novel economic markets and to help China for achieving long-term economic development by securing networks of global supplies of energy.

Beijing's engagement policy remains the need to secure essential resources of energy needed to sustain a rapid commercial development in the face of increasingly volatile global energy markets. China's consumption of energy is projected to exceed the demands of the US and may reach $18 \mathrm{Mb}$ daily by 2035. China has long followed its "win-win" strategy, which means that all trading partners of the region profit fairly and that China needs the Middle Eastern gas and 
oil, while countries of the Middle East desire access to the economic market of China, which provides grounds for the establishment of mutual collaboration.

\section{LIMITATION AND STUDY FORWARD}

The study is limited to evaluating the BRI as a substantial actor in the regional framework of the Middle East, which could be used as soft power leverage by China for establishing peace and tranquillity through mutual advantages. A more detailed further study could be done on this, as it is estimated that China aims to invest and develop infrastructure in the Middle East and other parts of the world from the commercial point of view. Through its BRI venture, it will associate the hunt for global energy resources with the diversification of the economic markets of the Middle East in the future.

\section{ACKNOWLEDGEMENT}

This study bears no conflict of interest and that the authors have not received financial support from any source.

\section{AUTHOR'S CONTRIBUTION}

Fakhar Hussain and Sarfraz Husain wrote the paper. Dr. Mian Muhammad Saeed searched the relevant data and worked on research methodology. Dr. Shumaila Rafiq evaluated the data. Umm-E-Rubab worked on references and review of the literature. Sarfraz Hussain framed the research design and edited the manuscript.

\section{REFERENCES}

1. Alterman, J., \& Graver, J. (2008). The Vital Triangle China, The United States, and The Middle East. Washington D.C: Centre for Strategic Studies and International Studies.

2. Besada, H., \& Salam, J. (2017). China's Energy Strategy in the MENA Region. China Quarterly of International Strategic Studies, 3(4), 597-619. https://doi.org/10.1142/S2377740017500269

3. Blanchard, J. M. (2021). Belt and Road Initiative (BRI) Blues: Powering BRI Research Back on Track to Avoid Choppy Seas. Journal of Chinese Political Science, 26, 235-255. https://doi.org/10.1007/s11366-020-09717-0

4. Camille, L., Jonathan, F., Degang, S., \& Naser, A.-T. (2019, October). China's Great Game In The Middle East. Retrieved May 15, 2021, from European Council on Foreign Relations: http;//css.ethz.ch/content/specia linterest/gess/cis/centre-for-securities-studies/en/services/publications/publication.html/fa508f69-ebc1-40a0-bf Of- f8e0610995de

5. Chris, Z., \& Brandon, G. (2008). China through Arab Eyes: American Influence in the Middle East. Parameters. 38(1), 60-72.

6. Ehteshami, A. (2018). Gold at the end of the Rainbow? The BRI and the Middle East. Global Policy, 9(3), 387397. https://doi.org/10.1111/1758-5899.12552

7. Engin, K. (2015). China's Middle East Energy Policies. International Journal of Social Sciences and Education Research, 1(1), 346-354. https://doi.org/10.24289/ijsser.106431

8. Garlick, J. (2020). The Regional Impacts of China's Belt and Road Initiative. Journal of Current Chinese Affairs, 49(1), 3-12. https://doi.org/10.1177/1868102620968848

9. Gordon, H., \& Noureddin M., Z. (2019, January). A New Great Power Engages with the Middle East: China's Middle East Balancing Approach. Retrieved May 18, 2021, from University of Alberta: http://era.library.u alberta.ca/items/1b3e3afa-8065-4d13-8dea-fa7629e2aca6

10. Guang, P. (2008). China's Energy Strategy and Primary Role of the Middle East in This Strategy. Journal of Middle Eastern and Islamic Studies (in Asia), 2(2), 62-72. https://doi.org/10.1080/19370679.2008.12023117

11. Himaz, R. (2019). Challenges associated with the BRI: a review of recent economic literature. The Service Industries Journal, 41(7-8), 512-526. https://doi.org/10.1080/02642069.2019.1584193

12. Hussain, F., \& Hussain, M. (2017). China-Pak Economic Corridor (CPEC) and Its Geopolitical Paradigms. International Journal of Social Sciences, Humanities and Education, 1(2), 79-95.

13. James M, D. (2017). China and the Middle East: Venturing into the Maelstrom. Asian Journal of Middle Eastern and Islamic Studies, 11(1), 1-14. https://doi.org/10.1080/25765949.2017.12023322

14. James, C. (2011, December). The Emergence of China in the Middle East. Retrieved May 17, 2021, from National Defense University: http://http://www.ndu.edu/inss.

15. John, M. (2014, May). Asia's Oil Supply: Risks and Pragmatic Remedies. Retrieved May 14, 2021, from Chatham House: http://http://www.chathamhouse.org/sites/files/Chathamhouse/field/field_document/2014 0506Asia'sOilSupplyMitchell.pdf.

16. Johnston, L. (2018). The Belt and Road Initiative: What is in it for China? Asia \& the Policy Studies, 6(1), 4058. https://doi.org/10.1002/app5.265

17. Jon, B., A. (2013, August). China's Balancing Act in the Gulf. Retrieved May 14, 2021, from Center for Strategic and International Studies (CSIS): http://http://www.csis.org/mideast

18. Lisa, W. (2019, December). The Middle East and China's Belt and Road Initiative. Retrieved May 18, 2021, from Center for Security Studies (CSS): http://www.css.ethz.ch/en/publications/css-analyses-in-securitypolicy.html 
19. Manochehr, D., \& James, E. (2013). The Dragon Nests: China's Energy Engagement of the Middle East. China Report, 49(1), 43-67. https://doi.org/10.1177/0009445513479243

20. Massoud, D. (2009). China and the Middle East: Establishing a New Partnership. Journal of Middle Eastern and Islamic Studies (in Asia), 3(1), 18-26. https://doi.org/10.1080/19370679.2009.12023120

21. Michal, M. (2016). The Structure of China's Oil Industry: Past Trends and Future Prospects. Oxford: Oxford Institute for Energy Studies.

22. Mordechai, C. (2019). China's Economic Diplomacy Approach in the Middle East Conflicts. China Report, 55(1), 24-39. https://doi.org/10.1177/0009445518818210

23. Naser, A.-T. (2012, June 27). China-Saudi Arabia Relations: Economic Partnership or Strategic Alliance?. Retrieved May 13, 2021, from Durham Research Online: http://www.dro.dur.ac.uk/9683/

24. Qian, X. (2014). Protecting China's Energy Interests in the Middle East. Journal of Middle Eastern and Islamic Studies (in Asia), 8(3), 48-69. https://doi.org/10.1080/19370679.2014.12023247

25. Rasel, M., Jiao, G., Yusufzada, S., Chanthamith, B., \& Sultana, A. (2020). Belt and Road Initiative (BRI) of China: Connecting the World for Sustainable Economic Development. Open Journal of Social Sciences, 8, 109120. https://doi.org/10.4236/jss.2020.81009

26. Sarieddine, T. (2021). Middle Kingdom Enters Middle East: A World-Systems Analysis of Peripheralization along the Maritime Silk Economictiative. Journal of World-Systems Research, 27(1), 177-201. https://doi.org/10.5195/jwsr.2021.1027

27. Sharma, A. (2019). An analysis of 'Belt and Road' Initiative and the Middle East. Asian Journal of Middle Eastern and Islamic Studies, 13(1), 35-49. https://doi.org/10.1080/25765949.2019.1586179

28. Shichor, Y. (2018). China's Belt and Road Initiative Revisited: Challenges and Ways Forward. China's Quarterly of International Strategic Studies, 4(1), 39-53. https://doi.org/10.1142/S237774001850001X

29. Sun, D. (2011). Six Decades of Chinese Middle East Studies: A Review. The Middle East Book Review, 2(1), 15-32. https://doi.org/10.1163/187853011X564399

30. Zha, D., \& Michal, M. (2015, October). China and the Middle East in a New Energy Landscape. Retrieved May 14, 2021, from Chatham House: http://www.chathamhouse.org

31. Zhao, H. (2007). China's Oil Venture in Africa. East Asia, 24(4), 399-415. https://doi.org/10.1007/s12140-0079027-7

32. Zhexin, Z. (2018). The Belt and Road Initiative: China's New Geopolitical Strategy? China's Quarterly of International Strategic Studies, 4(3), 327-343. https://doi.org/10.1142/S2377740018500240

33. Zhiqun, Z. (2009). China's New Diplomacy in the Middle East and Its Implication for the United States. Journal of Middle Eastern and Islamic Studies (in Asia), 3(4), 41-52. https://doi.org/10.1080/193 $\underline{70679.2009 .12023141}$ 